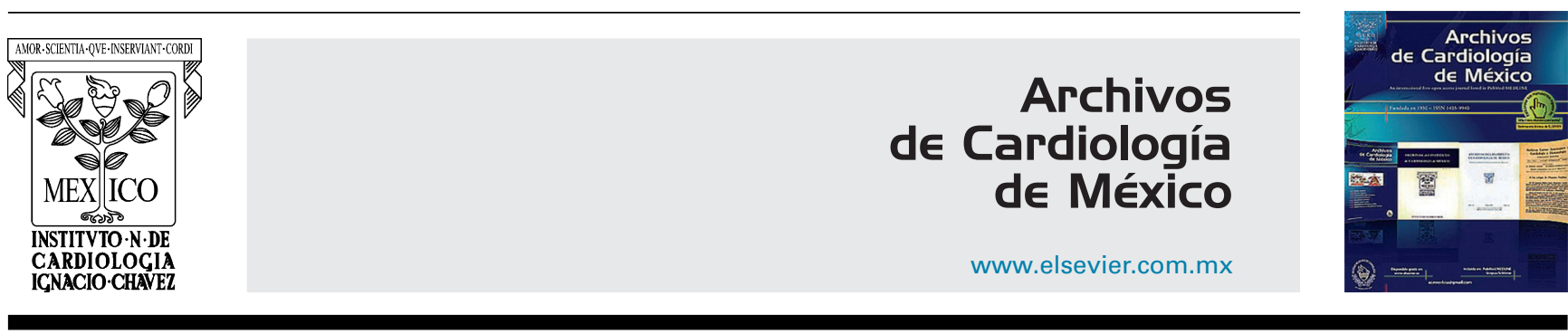

CLINICAL RESEARCH

\title{
Effect of physical training on the recovery of acute exercise, among patients with cardiovascular disease
}

\section{Marianna García-Saldivia ${ }^{a}$, Hermes Ilarraza-Lomelí ${ }^{a, *}$, Jonathan Myers ${ }^{\mathrm{b}}$, Jorge Lara ${ }^{a}$, Leopoldo Bueno ${ }^{\text {a }}$}

\author{
a Servicio de Rehabilitación Cardiaca, Instituto Nacional de Cardiología Ignacio Chávez, Mexico \\ b Veterans Affairs Palo Alto Health Care System, Stanford University, Palo Alto, CA, United States
}

Received 28 September 2016; accepted 9 November 2016

\author{
KEYWORDS \\ Cardiac \\ rehabilitation; \\ Cardiovascular \\ disease; \\ Recovery heart rate; \\ Cardiopulmonary \\ exercise testing; \\ Oxygen uptake \\ recovery; \\ México
}

\begin{abstract}
Introduction: Physical training programs (PTP) have shown several beneficial effects for patients with cardiovascular disease (CVD), particularly by increasing survival and quality of life. Physiological response during the effort and recovery phases of an exercise testing, is one of the strongest prognostic markers among patients with CVD. A reasonable mechanism that explains those training effects on survival is through the adaptations seen on heart rate recovery (HRR) and oxygen uptake kinetics at the post-exertional phase $\left(\mathrm{RVO}_{2}\right)$.

Objective: Compare the HRR and $\mathrm{RVO}_{2}$ values before and after a PTP in patients with CVD.

Methods: We studied a cohort of patients included in a cardiac rehabilitation program, whom performed a cardiopulmonary exercise testing (CPX). Then, risk stratification and an individualized exercise training program were performed. The exercise training program included 20 sessions of aerobic exercise, $30 \mathrm{~min}$ a day, five times a week, at moderate intensity. Finally, a second CPX was performed.

Results: A total of 215 patients were included. Peak oxygen uptake values rose $2.2 \pm 5.2 \mathrm{ml} / \mathrm{kg} / \mathrm{min}(p<0.001)$, HRR increased $1.6 \pm 10 \mathrm{bpm}(p<0.05)$ and $\mathrm{RVO}_{2}$ improved $-21 \pm 98 \mathrm{~s}(p<0.001)$. A post-hoc analysis show that the percentage of maximum heart rate remained statistically associated with HRR increment. Furthermore, diabetes and sedentarism were strongly related to $\mathrm{RVO}_{2}$ improvement.

No correlation between $\mathrm{HRR}$ and $\mathrm{RVO}_{2}$ was found $\left(R^{2}=0.002\right)$.

Conclusion: Physical exercise was associated with a beneficial effect on HRR and $\mathrm{RVO}_{2}$. Nevertheless, both variables were statistically unrelated.

(c) 2016 Instituto Nacional de Cardiología Ignacio Chávez. Published by Masson Doyma México S.A. This is an open access article under the CC BY-NC-ND license (http://creativecommons. org/licenses/by-nc-nd/4.0/).
\end{abstract}

\footnotetext{
* Corresponding author at: Juan Badiano No. 1, Colonia sección XVI, Delegación Tlalpan, México, D.F., Mexico. Tel.: +52 5573 2911x1214; fax: +52 55730994.

E-mail address: hermes_ilarraza@yahoo.com (H. Ilarraza-Lomelí).
} 


\author{
PALABRAS CLAVE \\ Rehabilitación \\ cardiaca; \\ Enfermedad \\ cardiovascular; \\ Recuperación de la \\ frecuencia cardiaca; \\ Prueba de esfuerzo \\ cardiopulmonar; \\ Cinética de \\ recuperación del \\ consumo de oxigeno; \\ México
}

\author{
Efecto del entrenamiento físico en la recuperación del ejercicio agudo, en pacientes \\ con enfermedad cardiovascular
}

\begin{abstract}
Resumen
Introducción: Los programas de entrenamiento físico han demostrado efectos benéficos en pacientes con enfermedad cardiovascular, particularmente debido al aumento de la supervivencia y calidad de vida. La respuesta fisiológica durante la prueba de esfuerzo cardiopulmonar tanto en las fases de ejercicio como de recuperación son de los principales marcadores pronósticos debido a la adaptación en la recuperación de la frecuencia cardiaca (RFC) y la cinética de recuperación de oxígeno en la fase de postesfuerzo $\left(\mathrm{RVO}_{2}\right)$.

Objetivo: Comparar los valores de $\mathrm{RFC}_{\mathrm{y}} \mathrm{RVO}_{2}$ antes y después de un programa de entrenamiento físico.

Métodos: Se estudió una cohorte de pacientes incluidos en un programa de rehabilitación cardiaca, que hayan realizado una prueba de esfuerzo cardiopulmonar. El programa de entrenamiento consistió en 20 sesiones de ejercicio aeróbico de 30 min diarios, 5 veces a la semana de intensidad moderada. Por último, se realizó una segunda prueba de esfuerzo cardiopulmonar. Resultados: Se incluyeron 215 pacientes. El consumo pico de oxígeno aumentó en $2.2 \pm 5.2 \mathrm{ml} / \mathrm{kg} / \mathrm{min}(\mathrm{p}<0.001)$, la RFC se incrementó $1.6 \pm 10 \mathrm{lpm}(\mathrm{p}<0.05)$ y mejoró la $\mathrm{RVO}_{2}$ $-21 \pm 98 \mathrm{seg}(\mathrm{p}<0.001)$. En el análisis post-hoc se observó que el porcentaje de la frecuencia cardiaca máxima se mantuvo asociado con el incremento de la RFC. Por otra parte, la diabetes y el sedentarismo estuvieron fuertemente asociados con la mejora de la $\mathrm{RVO}_{2}$. No se observó correlación entre RFC y $\mathrm{RVO}_{2}\left(\mathrm{R}^{2}=0.002\right)$.

Conclusiones: El ejercicio físico se asoció con un efecto benéfico sobre la RFC y la $\mathrm{RVO}_{2}$. Sin embargo, ambas variables no se relacionaron estadísticamente.

(C) 2016 Instituto Nacional de Cardiología Ignacio Chávez. Publicado por Masson Doyma México S.A. Este es un artículo Open Access bajo la licencia CC BY-NC-ND (http://creativecommons. org/licenses/by-nc-nd/4.0/).
\end{abstract}

\section{Introduction}

Exercise testing has been widely used for decades as a diagnostic tool in patients with cardiovascular disease (CVD), but it has also a prognostic approach at intermediate and long term. ${ }^{1,2}$ Variables traditionally used for prediction models, are focused on the active part of this test (exercise), specifically on two items: maximal exercise tolerance (maximal oxygen uptake, $\mathrm{VO}_{2} \max$ ) and chronotropic response.

Nowadays, there are some recognized physiological disorders during the recovery phase among CVD patients, like a slow heart rate recovery (HRR) and an abnormal $\mathrm{VO}_{2}$ kinetics. These changes are associated with a poor survival, in patients with CVD. ${ }^{3-6}$ It has been reported, that individuals with heart failure have elevated both, oxygen debt and oxygen deficit. These phenomena are related with a slow recovery of the $\mathrm{VO}_{2}$ kinetics $\left(\mathrm{RVO}_{2}\right)$ and also a reduced $\mathrm{HRR}$. Some researching groups have reported that this could be mediated by several neuro-humoral and local mechanisms. ${ }^{7}$

Physical training programs (PTP) have been associated with an increased on survival and better cardiovascular behavior among patients with heart disease. Particularly, it has been observed that PTP are linked to specific metabolic changes, such as a higher $\mathrm{VO}_{2} \max$, and a reduced oxygen debt. $^{8}$

Some studies have shown that PTP are associated with an improvement of HRR (increase) in patients with CVD. ${ }^{9}$ Nonetheless, this behavior has not yet been related with a reduction on oxygen debt.

Thus, we hypothesize that PTP could modify both, $\mathrm{HRR}$ and $\mathrm{RVO}_{2}$ behavior, because of their effects on the autonomic nervous system regulation and some local processes. The aim of this study was to compare HRR and $\mathrm{RVO}_{2}$ after a physical training program.

\section{Methods}

Selection criteria of this study included patients with cardiovascular disease, older than 18 years, who were referred to a hospital-outpatient cardiac rehabilitation program. Patients with any contraindication for exercising were excluded. Every patient was submitted into a risk stratification procedure that included: clinical examination, exercise testing and other evaluations as needed. Written consents were obtained from all patients.

Exercise Testing. All patients performed a cardiopulmonary exercise test (CPET), before and after the PTP. ${ }^{10}$ Every CPET was symptom's limited, and all CPET with more than $85 \%$ of the maximal predicted-heart rate (HRmax $=220-$ age in years), or a respiratory quotient (RQ) greater than 1.10, were considered maximal.

A SchillerCS- $200^{\circ}$ device with a treadmill was used. Electrocardiographic signal (ECG) was recorded throughout the test and blood pressure (BP) was measured every minute during exercise, and at the 1st, 3rd, 5th and 8th min of recovery using a calibrated aneroid sphygmomanometer. An automated medical gas analysis device (PowerCube ${ }^{\odot}$ ) was used to measure the volume, airflow and the fractional concentrations of oxygen and carbon dioxide in the exhaled air. Gas samples were printed every $10 \mathrm{~s}$. A face mask was used to collect expired air, taking care that it fitted properly and that there were no air leaks during exercise. 
A cardiac defibrillator and a fully stocked resuscitation cart were present at all times.

The gas analyzer was calibrated according to the manufacturer specifications before each test was performed. ECG leads were placed according to the Mason-Likar method. Initially, skin was cleaned with an alcohol saturated cotton swab, and gentle abrasion of the skin's superficial layer was made with a fine abrasive paper. ${ }^{11}$ A resting 12 -lead ECG and spirometry were performed prior to the test. CPET began with a 3 min resting period, and all subjects performed the same treadmill Balke ramp-protocol. Once maximal exercise was achieved, subjects continued to walk for 3 min at $2 \mathrm{~km} / \mathrm{h}$ at $0 \%$ elevation. Following the $3 \mathrm{~min}$ walking period, subjects rested in the supine position for an additional 5 min. $^{12}$

All patients were instructed to express symptoms during exercise including chest pain, dyspnea or palpitations. Heart rate (HR) was obtained from the continuous ECG signal. HR at rest (HRrest) was measured when the patient was seated for at least 3 min immediately prior to beginning exercise. Peak HR (HRpeak) and HR reserve (RHR) were used to evaluate the chronotropic response to exercise. RHR was the difference between HRrest and HRpeak. Heart rate recovery was obtained by subtracting $H R$ at the first minute of recovery from the HRpeak. ${ }^{4}$ The predicted maximal HR was calculated as follows: HRmaxpred $=220$ - age in years.

Myocardial oxygen uptake $\left(\mathrm{MVO}_{2}\right)$ was estimated using the product of heart rate and systolic blood pressure (double product, DP). The presence of arrhythmias, ST-segment anomalies, or other ECG disturbances was recorded.

The cardiopulmonary response to exercise was evaluated using expired gases, and the following variables were obtained: minute ventilation (VE), respiratory quotient $(\mathrm{RQ})$, oxygen uptake $\left(\mathrm{VO}_{2}\right)$ at the aerobic-anaerobic threshold (AT) and maximal effort $\left(\mathrm{VO}_{2}\right.$ peak), ventilator equivalent for carbon dioxide slope $\left(\mathrm{VE} / \mathrm{VO}_{2}\right)$, oxygen pulse $\left(\mathrm{PO}_{2}\right)$, and $\mathrm{VO}_{2}$ recovery $\left(\mathrm{RVO}_{2}\right)$. $\mathrm{RVO}_{2}$ was identified measuring the time needed for returning oxygen uptake to half of its peak value. ${ }^{13}$

Physical Training Program. Once the first CPET was obtained, a trained cardiologist has prescribed all exercise parameters, based on each cardiovascular riskstratification. ${ }^{14}$ Every patient performed one indoor cycling session daily for 4 week ( 20 sessions) and lasting 30 min each. All participants also performed general gymnastics twice a week. Ergometer workload was controlled using a heart rate feedback mechanism. Perceived exertion effort was moderate (Borg scale 12-13). Every session had three phases: warming up, main phase and cooling down. Cardiac Rehabilitation Program included also: education, exercise, nutrition and psychological advice.

\section{Statistical analysis}

Statistical analysis was performed using SPSS 19.0 software. Nominal and categorical variables were presented as frequencies and percentages, and compared using the chi square test or the Fisher exact test. Continuous variables are presented as mean and reference intervals ( $\mathrm{Cl} 95 \%)$.
A two sample $t$-test for independent variables and oneway ANOVA were used to compare means of those variables with normal Gaussian distribution (Kolmogorov-Smirnov test), and the Mann-Whitney $U$ test was used for numerical variables without normal distribution. Variables were plotted, bivariate analyses were performed, and all $r$ and $p$ values were derived using the Pearson test. Variables that demonstrated to be statistically significant were included in a multiple regression model (forward stepwise). All $p$ values less than 0.05 were considered significant.

\section{Results}

A total of 215 patients and 430 CPET were analyzed. Demographic and PTP characteristics are shown in (Table 1). After PTP, exercise time and $\mathrm{VO}_{2}$ peak increased in all patients $\left(0.7 \pm 0.1 \mathrm{~min}, \quad p<0.001\right.$ and $2.2 \pm 5.2 \mathrm{mlO}_{2} / \mathrm{kg} / \mathrm{min}$, $p<0.001$ respectively), meanwhile heart rate and double product at rest decreased $(2.7 \pm 12 \mathrm{bpm}, \quad p<0.001$ and $570 \pm 1700 \mathrm{bpm} / \mathrm{mmHg}, p<0.001)$.

Cardiopulmonary exercise testing variables, before and after physical training are presented in (Table 2). Performance during recovery phase of acute exercise improved (Fig. 1); heart rate recovery augmented $1.6 \pm 10 \mathrm{bpm}$ $(p<0.05)$ and $\mathrm{RVO}_{2}$ diminished $21 \pm 98 \mathrm{~s}(p<0.01)$. Bivariate

\begin{tabular}{|c|c|}
\hline Variables & All \\
\hline Patients ( $n, \%)$ & $215(100 \%)$ \\
\hline Age (years) & $57 \pm 13$ \\
\hline Gender ( $n, \%)$ & $\begin{array}{l}F=47(22 \%) \\
M=168(78 \%)\end{array}$ \\
\hline BMI $\left(\mathrm{kg} / \mathrm{m}^{2}\right)$ & $27 \pm 5$ \\
\hline Hypertension ( $n, \%)$ & $33(15 \%)$ \\
\hline Smoking $(n, \%)$ & $125(58 \%)$ \\
\hline Diabetes mellitus $(n, \%)$ & $19(9 \%)$ \\
\hline Ischemic heart disease $(n, \%)$ & $178(83 \%)$ \\
\hline Valvular heart disease $(n, \%)$ & $12(6 \%)$ \\
\hline Congenital heart disease $(n, \%)$ & $3(1 \%)$ \\
\hline Idiopathic cardiomyopathy ( $n$, \%) & $19(9 \%)$ \\
\hline Other pathologies $(n, \%)$ & $3(1 \%)$ \\
\hline $\operatorname{LVEF}(\%)$ & $44 \pm 14$ \\
\hline Bet-blockers ( $n, \%)$ & $188(87 \%)$ \\
\hline Nitrates $(n, \%)$ & $54(25 \%)$ \\
\hline Digoxin $(n, \%)$ & $52(24 \%)$ \\
\hline $\operatorname{ACE}-\operatorname{ARB}(n, \%)$ & $187(87 \%)$ \\
\hline $\operatorname{CCB}(n, \%)$ & $39(18 \%)$ \\
\hline Antiarrhythmic ( $n, \%)$ & $21(9 \%)$ \\
\hline Training sessions $(n)$ & $20 \pm 4$ \\
\hline Load increase (W) & $29 \pm 15$ \\
\hline Training HR (bpm) & $103 \pm 15$ \\
\hline
\end{tabular}

Abbreviations: $\mathrm{F}$, female; $\mathrm{M}$, male; $\mathrm{BMI}$, body mass Index; LVEF, left ventricle ejection fraction; ACE-ARB, angiotensinconverting enzyme inhibitors-angiotensin-II receptor blocker; CCB, calcium channel blocker; W, watts; HR, heart rate; bpm, beat per minute. Demographic variables and physical training characteristics of patients are displayed. 
Table 2 Cardiopulmonary response before and after physical training program.

\begin{tabular}{|c|c|c|c|c|}
\hline Variables & $\begin{array}{l}\text { CPET } 1 \\
(x \pm D E)\end{array}$ & $\begin{array}{l}\text { CPET } 2 \\
(x \pm D E)\end{array}$ & $\begin{array}{l}\text { Difference } \\
(x \pm D E)\end{array}$ & $p^{*}$ \\
\hline HR rest (bpm) & $69 \pm 12$ & $67 \pm 11$ & $-2.7 \pm 12$ & $<0.001$ \\
\hline SBP rest $(\mathrm{mmHg})$ & $116 \pm 17$ & $113 \pm 15$ & $-3.3 \pm 1$ & $<0.01$ \\
\hline DBP rest $(\mathrm{mmHg})$ & $76 \pm 11$ & $73 \pm 10$ & $-2.3 \pm 0.7$ & $<0.01$ \\
\hline $\mathrm{DP}$ rest $(\mathrm{bpm} / \mathrm{mmHg})^{*} 1000$ & $8.78 \pm 1.7$ & $7.5 \pm 1.3$ & $-0.57 \pm 1.7$ & $<0.001$ \\
\hline Exercise time $(\mathrm{min})$ & $6.2 \pm 2$ & $6.9 \pm 2$ & $0.7 \pm 0.1$ & $<0.001$ \\
\hline HR peak (bpm) & $128 \pm 23$ & $132 \pm 25$ & $4 \pm 19$ & $<0.05$ \\
\hline SBP peak (mmHg) & $147 \pm 27$ & $146 \pm 26$ & $-1 \pm 21$ & ns \\
\hline DBP peak $(\mathrm{mmHg})$ & $88 \pm 14$ & $86 \pm 14$ & $2 \pm 12$ & ns \\
\hline DP peak $(\mathrm{lpm} / \mathrm{mmHg})^{*} 1000$ & $18.9 \pm 5.2$ & $19.4 \pm 5.6$ & $0.5 \pm 4.3$ & ns \\
\hline PMPHR (\%) & $79 \pm 13$ & $81 \pm 14$ & $2.3 \pm 12$ & $<0.01$ \\
\hline RHR (bpm) & $59 \pm 22$ & $65 \pm 24$ & $6 \pm 19$ & $<0.001$ \\
\hline ST segment depression (mm) & $0.4 \pm 0.9$ & $0.4 \pm 0.9$ & $0.01 \pm 0.8$ & ns \\
\hline Pulse of oxygen (ml/beat) & $77 \pm 22$ & $85 \pm 22$ & $8.1 \pm 26$ & $<0.001$ \\
\hline VA score & $-0.3 \pm 5$ & $-1.7 \pm 5$ & $-1.4 \pm 3$ & $<0.001$ \\
\hline Duke score & $3.2 \pm 6$ & $4.4 \pm 6$ & $1.2 \pm 5.1$ & $<0.001$ \\
\hline RQ peak & $1.11 \pm 0.1$ & $1.13 \pm 0.1$ & $0.02 \pm 0.2$ & ns \\
\hline $\mathrm{VO}_{2} \mathrm{AT}(\mathrm{ml} / \mathrm{kg} / \mathrm{min})$ & $15 \pm 5$ & $16 \pm 5$ & $1 \pm 4.4$ & $<0.05$ \\
\hline $\mathrm{VO}_{2}$ peak (ml/kg/min) & $19 \pm 6$ & $21 \pm 7$ & $2.2 \pm 5.2$ & $<0.001$ \\
\hline $\mathrm{VE} / \mathrm{VCO}_{2}$ slope & $31 \pm 6$ & $30 \pm 7$ & $-1 \pm 6$ & ns \\
\hline $\mathrm{MVO}_{2}$ & $20 \pm 8$ & $21 \pm 8$ & $1 \pm 6$ & ns \\
\hline HRR (bpm) & $15 \pm 10$ & $16.6 \pm 10$ & $1.6 \pm 10$ & $<0.05$ \\
\hline $\mathrm{RVO}_{2}$ (seg) & $249 \pm 97$ & $228 \pm 81$ & $-21 \pm 98$ & $<0.01$ \\
\hline
\end{tabular}

analysis showed that variables associated with an improvement on HRR or $\mathrm{RVO}_{2}$ were different. On one hand, those variables highly correlated with HRR were: spironolactone, chronotropic index, reserve heart rate, percentage of maximal predicted heart rate (PMPHR), DPmax, $\mathrm{MVO}_{2}$. On the other hand, variables associated with $\mathrm{RVO}_{2}$ were: diabetes mellitus, hypertension, sedentarism, age, METs, exercise time, oxygen pulse, Duke Treadmill Score and Veterans Affairs Score. All $p$ values $<0.05$.

These variables were included into two logistic regression models, one for HRR and another for $\mathrm{RVO}_{2}$. According to HRR, the only variable that remained significant after
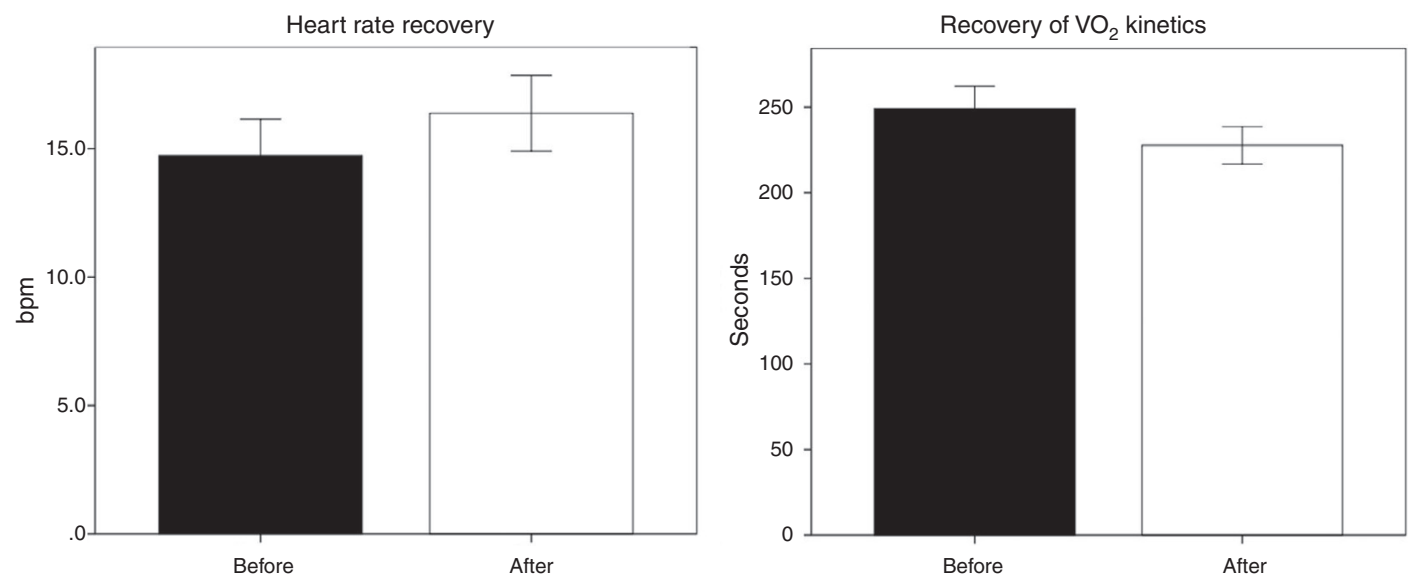

Figure 1 Abbreviations: beats per minute (bpm). Cardiopulmonary recovery behavior improved after a physical training program (a) shows a significant increase of heart rate recovery $(p<0.05)$, and (b) a reduction of oxygen uptake kinetics recovery time $(p<0.01)$. 


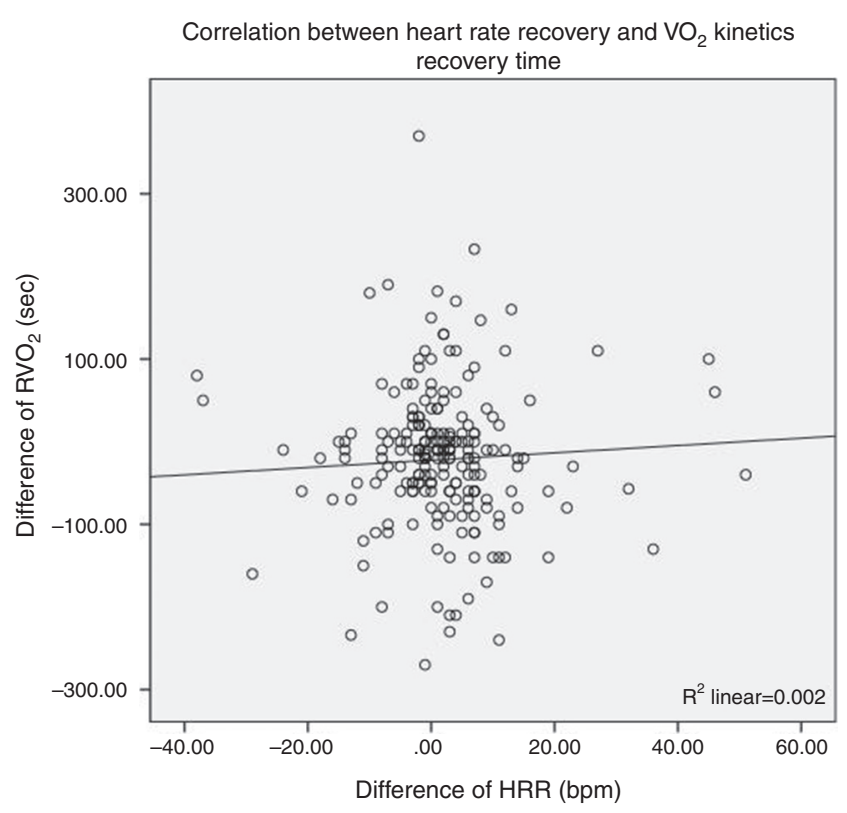

Figure 2 Abbreviations: Recovery of oxygen uptake $\left(\mathrm{RVO}_{2}\right)$ and heart rate recovery (HRR). This scatter plot shows an absence of correlation between heart rate recovery and the recovery of oxygen uptake, $\left(R^{2}=0.002, p=\mathrm{ns}\right)$.

multivariable analysis was PMPHR. In contrast, those variables associated with $\mathrm{RVO}_{2}$ were: diabetes mellitus and sedentarism.

On (Fig. 2), it is presented the lack of correlation between HRR and $\mathrm{RVO}_{2}$ before and after PTP. $\left(R^{2}=0.002\right.$, $p=\mathrm{ns})$.

\section{Discussion}

On this study we found that a four week physical training program is associated with an improvement of fitness. These findings complement those found in previous studies in patients with coronary artery disease. ${ }^{15-17}$

We identified that after training, $68 \%$ of patients increase their $\mathrm{VO}_{2}$ peak, 54\% augmented heart rate recovery, and $39 \%$ improved $\mathrm{RVO}_{2}$. Jolly et al., published that only $41 \%$ of patients increased HRR, and this change was associated with variables such as age, peripheral arterial disease, diabetes mellitus, heart failure and the use of nitrates. ${ }^{18}$

In our studied population, after multivariate analysis we observed that only chronotropic response was highly associated with HRR improvement. It is remarkable that only 39 percent of our patients improved their $\mathrm{RVO}_{2}$ after physical training. This response was statistically associated with the presence of sedentarism and diabetes mellitus. We think that these changes in $\mathrm{VO}_{2}$ kinetics, are probably due to several metabolic adaptations, promoted by changes of muscular tissue, either at myocardial or peripheral level. 8,19 Furthermore, it has been reported that some patients with CVD, specifically those patients with heart failure have a slow oxygen uptake kinetics recovery. ${ }^{10}$ We saw that patients who improved exercise recovery, did it regardless their left ventricle systolic function.
Previous studies suggested that an inadequate $\mathrm{RVO}_{2}$ might be related with a slow supply energy at skeletal muscle, as reported by Cohen-Solal et al. ${ }^{20}$

Another explanation to the lack of agreement among fitness, HRR and recovery of $\mathrm{VO}_{2}$ is that, physiological response to exercise training depends directly on the intensity of effort and the number of sessions. In our study, probably a training period of 4 weeks duration and moderate intensity was enough to improve fitness, but not to promote changes in the other two variables. ${ }^{21}$

Some recognized mechanisms, related to $\mathrm{RVO}_{2}$ behavior are: re-synthesis of ATP, glycogen synthesis from blood lactate (Cori cycle); redistribution of oxygen content (blood, myoglobin and interstitial fluid), and the thermogenic effect of core temperature elevation, associated with the action of catecholamines. $^{22}$

Initially, HRR and recovery of $\mathrm{VO}_{2}$ seemed to be closely related. Nevertheless, our results pointed out that, factors associated with HRR improvement were different to those related to a better recovery of $\mathrm{VO}_{2}$. This evidence showed that both variables may be determinated by different physiological and pathophysiological processes, as suggested by Myers et al., about the role of the autonomic nervous regulation on the heart rate, regardless the metabolic state. ${ }^{23}$

A limitation on this research could be that our studycohort was conducted at only one institution, and it was self-controlled (before-after). It is worth to mention that looking for a control group on this kind of therapy is ethically questionable. We believe that this topics need to be further studied, using more specific and long-term designs.

In conclusion the physical exercise in patients with cardiovascular disease is associated with improved recovery of heart rate and oxygen consumption recovery. These variables separately were significantly associated with heart rate reserve in the stress test.

However, a linear correlation between $\mathrm{HRR}$ and $\mathrm{RVO}_{2}$ was not observed. This lack of association may be because they are different factors that determine the behavior of each of these two variables.

\section{Ethical disclosures}

\section{Protection of human and animals subjects}

The authors state that no experiments have been performed on humans or animals for this research.

Confidentiality of data. The authors state that they have followed the protocols of their work center on the publication of patient data.

Right to privacy and informed consent. The authors state that no patient data appears in this article.

\section{Funding}

This research received no specific grant from any funding agency in the public, commercial, or not-for-profit sectors. 


\section{Conflict of interest}

The authors declare that there is no conflict of interest.

\section{Acknowledgements}

To all the personal of Cardiac Rehabilitation Service of the Instituto Nacional de Cardiología Ignacio Chávez for their daily work, making this cardiac rehabilitation cohort possible.

\section{References}

1. Arena R, Sietsema K. Exercise testing in the clinical evaluation of patients with heart and lung disease. Circulation. 2011;123:668-80.

2. Ilarraza-Lomelí $\mathrm{H}$. Prueba de ejercicio con análisis de gases espirados. Arch Cardiol Mex. 2012;82:160-9.

3. Myers J, Prakash M, Froelicher V, et al. Exercise capacity and mortality among men referred for exercise testing. N Engl J Med. 2002;346:793-801.

4. Cole CR, Blackstone EH, Pashkow FJ, et al. Heart rate recovery immediately after exercise as a predictor of mortality. N Engl J Med. 1999;341:1351-7.

5. Shetler K, Marcus R, Froelicher VF, et al. Heart rate recovery: validation and methodologic issues. J Am Coll Cardiol. 2001;38:1980-7.

6. de Groote P, Millaire A, Decoulx E, et al. Kinetics of oxygen consumption during and after exercise in patients with dilated cardiomyopathy. New markers of exercise intolerance with clinical implications. J Am Coll Cardiol. 1996;28: 168-75.

7. Camps A. Consumo de oxígeno posejercicio después de un ejercicio continuo y otro interválico en tapiz rodante. Apuntes Educación Física y Deportes. 2011;104:21-7.

8. Pioli S. Effect of exercise on the heart and the prevention of coronary heart disease. In: Froelicher V, Myers J, editors. Effect of exercise on the heart and the prevention of coronary heart disease. 5th ed. Philadelphia: Saunders; 2006. p. 456.

9. Ilarraza-Lomelí H, Barrera-Ramírez CF, Hernández-Félix MP. Influencia del entrenamiento físico en el comportamiento de la frecuencia cardiaca durante la prueba de esfuerzo, en pacientes con cardiopatía isquémica. XXIV Congreso Nacional de Cardiología - XX Congreso Interamericano de Cardiología. Arch Cardiol Mex. 2005;75 Suppl. (4). S4-1-145.
10. American Thoracic Society. American College of Chest Physicians. ATS/ACCP statement on cardiopulmonary exercise testing. Am J Respir Crit Care Med. 2003;167:211-77.

11. Ilarraza-Lomelí H, Torres C, Mendoza B. Efecto de la preparación de la piel en su impedancia eléctrica. XXIII Congreso Nacional de Cardiología. Arch Cardiol Mex. 2003;73 Suppl. (2):1-135.

12. Lukaski H, Bolonchuk WW, Klevay LM. Comparison of metabolic responses and oxygen cost during maximal exercise using three treadmill protocols. J Sports Med Phys Fitness. 1989;29:223-9.

13. Tanabe Y, Takahashi M, Hosaka Y, et al. Prolonged recovery of cardiac output after maximal exercise in patients with chronic heart failure. J Am Coll Cardiol. 2000;35:1228-36.

14. Ilarraza H, Quiroga P. Planeación del entrenamiento físico. In: Maroto J, editor. Rehabilitación cardiovascular. $1^{\text {a }}$ ed. Madrid: Editorial Panamericana; 2010. p. 253-73.

15. Ilarraza-Lomelí H, Barrera-Ramírez CF, Hernández-Félix MP. Influencia del entrenamiento físico en el comportamiento de la frecuencia cardiaca durante la prueba de esfuerzo, en pacientes con cardiopatía isquémica. XXIV Congreso Nacional de Cardiología - XX Congreso Interamericano de Cardiología. Arch Cardiol Mex. 2005;75 Suppl. (4). S4-1-145.

16. Snoek JA, van Berkel S, van Meeteren N, et al. Effect of aerobic training on heart rate recovery in patients with established heart disease; a systematic review. PLoS ONE. 2013;8(12): e83907, http://dx.doi.org/10.1371/journal.pone.0083907.

17. Ilarraza-Lomelí H, Myers J, Kottman W, et al. An evaluation of training responses using self-regulation in a residential rehabilitation program. J Cardiopulm Rehabil. 2004;24:27-33.

18. Jolly M, Brennan D, Cho L. Impact of exercise on heart recovery. Circulation. 2011;124:1520-6.

19. Wasserman K, Hansen JE, Sue DY, et al. Principles of exercise testing and interpretation: including pathophysiology and clinical applications. Philadelphia: Lippincott Williams \& Wilkins; 2005.

20. Cohen-Solal A, Laperche T, Morvan D, et al. Prolonged kinetics of recovery of oxygen consumption after maximal graded exercise in patients with chronic heart failure analysis with gas exchange measurements and NMR spectroscopy. Circulation. 1995;91:2924-32.

21. American College of Sports Medicine. ACSM's guidelines for exercise testing and prescription. 8th ed. Baltimore: Lippincott Williams \& Wilkins; 2009.

22. McArdle W, Katch F, Katch V. Exercise physiology, energy, nutrition and human performance. 6th ed. Philadelphia: Lippicott Williams \& Wilkins; 2007.

23. Myers J, Hadley D, Oswald U, et al. Effects of exercise training on heart rate recovery in patients with chronic heart failure. Am Heart J. 2007;153:1056-63. 